\title{
REPRODUCTIVE TOXICOLOGY \\ Effects of chemical mixtures on the ovary
}

\author{
Vasiliki E Mourikes and Jodi A Flaws \\ Department of Comparative Biosciences, University of Illinois at Urbana-Champaign, Urbana, Illinois, USA \\ Correspondence should be addressed to J A Flaws; Email: jflaws@uiuc.edu
}

This paper forms part of a special section on Reproductive toxicology. The guest editors for this section were Dr Adam Watkins (The University of Nottingham, UK) and Dr Aileen Keating (lowa State University, IA, USA)

\begin{abstract}
The ovaries play a critical role in female reproductive health because they are the site of oocyte maturation and sex steroid hormone production. The unique cellular processes that take place within the ovary make it a susceptible target for chemical mixtures. Herein, we review the available data regarding the effects of chemical mixtures on the ovary, focusing on development, folliculogenesis, and steroidogenesis. The chemical mixtures discussed include those to which women are exposed to environmentally, occupationally, and medically. Following a brief introduction to chemical mixture components, we describe the effects of chemical mixtures on ovarian development, folliculogenesis, and steroidogenesis. Further, we discuss the effects of chemical mixtures on corpora lutea and transgenerational outcomes. Identifying the effects of chemical mixtures on the ovaries is paramount to preventing and treating mixture-inducing toxicity of the ovary that has long-term consequences such as infertility and ovarian disease.

Reproduction (2021) 162 F91-F100
\end{abstract}

\section{Introduction}

The ovary is a complex heterogenous organ that is critical for reproductive and systemic health of women. The functional structures within the ovary are follicles at various stages of maturity as well as corpora lutea (CLs) (Guraya 1977). Follicles and CLs are held together by stromal tissue and are surrounded by a layer of germinal epithelium. Each mature follicle contains an oocyte, which is surrounded by many layers of hormonesecreting cells. These cells primarily secrete estradiol and testosterone (Guraya 1977). At its final stage of maturity, a follicle will ovulate, and the oocyte will be released into the oviduct. In response, the remaining cells undergo physical and chemical remodeling to form CLs. The primary function of a CL is to secrete progesterone, which moderates the onset and maintenance of pregnancy. If the oocyte is not fertilized and pregnancy does not occur, the $\mathrm{CL}$ regresses and the process of follicle maturation and ovulation begins again (Guraya 1977). The hormones secreted by follicles and CLs work in intricate feedback loops with gonadotropins and hypothalamic hormones in the hypothalamic-pituitarygonadal axis (Kaprara \& Huhtaniemi 2018). The structural diversity and unique biochemical processes that take place in the ovary provide many possible targets for chemical toxicants including pharmaceutical, occupational, and environmental agents.
At the present time, toxicological studies, as well as government exposure regulations, are primarily focused on individual chemicals. As such, a large gap in knowledge regarding the health effects of chemical mixtures exists in general, especially regarding the effects of mixtures on the ovary. Mixtures of chemicals are traditionally thought to act in one of three ways: (1) similar action of chemicals in the mixture, (2) dissimilar action of chemicals in the mixture, or (3) interactions of chemicals in the mixture (synergism or antagonism) (World Health Organization 2017). The assumption is made that chemicals that have similar or dissimilar actions do not interact and the toxicological profiles of each individual chemical remain unchanged in the mixture. The consensus in the United States (US) and the European Union (EU) is often that a mixture of chemicals can be assessed based on an assumption of additivity (World Health Organization 2017). That is, a mixture is deemed safe if all the individual chemical components are present at concentrations below the no observable adverse effect level (NOAL). However, epidemiological data, animal studies, and mechanistic data all support the notion that chemical interactions are far more complex and as such, chemicals must be studied in combination, regardless of their individual toxicological profiles. In this review, we discuss the effects of chemical mixtures on the ovary, with an emphasis on ovarian development, folliculogenesis, and 
steroidogenesis. These data collected from in vitro and in vivo experiments can be integrated to understand the mechanisms through which various chemical mixtures cause disruption in the ovarian processes within the whole animal.

\section{Chemical mixture components}

The chemical mixtures discussed in this review include agricultural chemicals, plasticizers, flame retardants, phytoestrogens, pharmaceuticals, cosmetic agents, and industrial by-products. Although some of the mixtures are composed of a single class of chemicals, others represent combinations of various classes of chemicals. Many of these chemicals have been individually identified as potent ovarian toxicants and their combinations in mixtures pose a unique threat to female reproductive health. Pesticides are primarily used in agricultural industries for large-scale crop production; however, they are also used in veterinary medicine as flea and tick preventatives for pets, and in human medicine as antifungal drugs. Pesticides accumulate in the environment and are often detected in house dust as well as on produce (Sciences 2020). Phthalates are ubiquitous industrial chemicals used as plasticizers and solvents in building materials, cosmetics, food storage containers, medical equipment, and children's toys (Zhou et al. 2017a). The mixtures discussed in this review are composed of both parent phthalate compounds as well as their monoester metabolites. Another class of plasticizers found in mixtures of ovarian toxicants are bisphenols. Bisphenols are plasticizers used in the manufacturing of polycarbonate plastics and epoxy resins. They are found in food storage containers, thermal receipt papers, medical equipment, and industrial piping (Ben-Jonathan \& Hugo 2016). Bisphenol A (BPA) has been studied extensively as a reproductive toxicant and it is found in the mixtures discussed in this review. Flame retardants are synthetic chemicals used in various industries to delay or prevent rapid thermal acceleration and fires. Commonly used classes of flame retardants include polychlorinated biphenyls (PCBs) and brominated flame retardants (BDEs). PCBs are synthetic chemicals used as coolants and lubricants in electrical equipment. Although PCBs are no longer produced in the US, they accumulate in the environment and do not break down easily (Agency 2020). As a result, women continue to be exposed to PCBs long after their removal from industrial markets in the US. Phytoestrogens are plant-derived chemicals that resemble estrogen in structure. Women are largely exposed to phytoestrogens through dietary supplements and consumption of phytoestrogen-rich foods like soy (Patisaul \& Jefferson 2010). The phytoestrogens discussed in this review include flavones and isoflavones. Pharmaceuticals are drugs synthesized for treating, curing, or preventing diseases. Although pharmaceutical drugs are intended to be beneficial therapeutics, they also can have adverse reproductive outcomes (Schmitz et al. 2018). Over the counter drugs and drugs used for the treatment of chronic conditions are of concern due to their extended period of use. Parabens are used as preservatives and anti-microbials in food products and cosmetics (Zhou et al. 2017a). Women are exposed to parabens by consumption of contaminated food products and the use of cosmetics. Chemical UV filters are another class of toxicants found in cosmetics. They are most commonly used in sunscreens, hairsprays, and other cosmetics to prevent damage from sun exposure (Zhou et al. 2017a). Women are exposed to chemical UV filters when they use sunscreens, hairsprays, and other cosmetics. Ovarian toxicants found in cosmetics and personal care products are of concern because data show that women use more of these products at a higher frequency than men (Zhou et al. 2017a). Polycyclic aromatic hydrocarbons (PAHs) are by-products of the incomplete combustion of organic materials including coal, gas, oil, and wood. According to the Centers for Disease Control (CDC), women are exposed to PAHs by inhaling contaminated air from cigarettes and vehicle exhausts as well as by consuming grilled or charred foods (Prevention 2009). Wastewater from hydraulic fracturing is another major source of exposure to industrial by-products. It is often highly contaminated with both organic and inorganic chemicals (Kassotis et al. 2016). Refer to Table 1 for a list of the individual chemicals found in the mixtures discussed in this review.

\section{Effects of chemical mixtures on ovarian development}

Through several complex processes, the ovaries of a developing fetus begin to form shortly after sex determination. Ovarian development begins with extensive proliferation of both primordial germ cells and somatic cells in clusters termed germ cell nests (Hirshfield 1991). Eventually, the somatic cells reorganize themselves to form a single layer around a germ cell nest and subsequently, the germ cell nests stop dividing and the cells in the nests undergo meiosis to form oocytes. After approximately $70 \%$ of oocytes in the germ cell nest undergo apoptosis, the nest breaks down and the somatic cells rearrange themselves to form a single layer around each surviving oocyte (Hirshfield 1991). This structure, which is complete with an individual oocyte surrounded by a single layer of granulosa cells, is called the primordial follicle. Females are born with a finite pool of resting primordial follicles (Guraya 1977). Throughout a female's reproductive lifespan, these follicles grow into more mature follicles capable of ovulation and production of sex steroid hormones. Healthy adult ovaries contain a diverse follicle pool including primordial, primary, secondary, and mature antral follicles (Hirshfield 1991). Exposures to chemical 
Table 1 Chemical mixture components.

\begin{tabular}{|c|c|c|c|c|}
\hline & Description & Exposure & Chemicals & References \\
\hline \multicolumn{5}{|l|}{ Pesticides } \\
\hline Insecticides & $\begin{array}{l}\text { Used in agricultural } \\
\text { industries for large scale } \\
\text { crop production; however, } \\
\text { they are also used in } \\
\text { veterinary medicine as } \\
\text { flea and tick preventatives } \\
\text { for pets }\end{array}$ & $\begin{array}{l}\text { Inhalation of house dust, } \\
\text { consumption of } \\
\text { contaminated foods }\end{array}$ & $\begin{array}{l}\text { DDT, DDD, DDE, MXC, DEET, } \\
\text { Permethrin aroclor, } \\
\text { chlordane, taxophene, } \\
\text { aldrin, dieldrin, } \\
\text { 1,2,4,5-tetrachlorobenzene, } \\
\alpha-\mathrm{HCH}, \beta-\mathrm{HCH}, \\
\text { hexachlorobenzene, mirex, } \\
\text { lindane, pentachlorobenzene }\end{array}$ & $\begin{array}{l}\text { Baldridge 2003, Rice et al. } \\
\text { 2006, Prevention 2009, } \\
\text { Wang et al. 2013, } \\
\text { Vannuccini et al. 2016, } \\
\text { Lea et al. 2016, Kaprara } \\
\text { \& Huhtaniemi 2018, } \\
\text { Pollock et al. 2018, } \\
\text { Johansson et al. 2020, } \\
\text { Meling et al. 2020 }\end{array}$ \\
\hline Fungicides & $\begin{array}{l}\text { Used in large scale } \\
\text { agricultural industries to } \\
\text { as well as in human and } \\
\text { veterinary medicine to } \\
\text { prevent fungal infestations } \\
\text { and treat fungal infections }\end{array}$ & $\begin{array}{l}\text { Consumption of } \\
\text { contaminated foods and } \\
\text { topical or oral medications }\end{array}$ & $\begin{array}{l}\text { Vinclozolin, prochloraz, } \\
\text { procymidone, epoxiconazole }\end{array}$ & $\begin{array}{l}\text { Baldridge 2003, } \\
\text { Gregoraszczuk et al. } \\
\text { 2005, Lea et al. } 2016\end{array}$ \\
\hline \multicolumn{5}{|l|}{ Plasticizers } \\
\hline $\begin{array}{l}\text { Phthalates and } \\
\text { phthalate } \\
\text { metabolites }\end{array}$ & $\begin{array}{l}\text { Used as plasticizers and } \\
\text { solvents in cosmetics, } \\
\text { food storage containers, } \\
\text { medical equipment, and } \\
\text { children's toys }\end{array}$ & $\begin{array}{l}\text { Consumption of } \\
\text { contaminated food } \\
\text { products and } \\
\text { environmental exposure } \\
\text { from bisphenols leaching } \\
\text { out of products }\end{array}$ & $\begin{array}{l}\text { DEP, DEHP, DBP, DiBP, DiNP, } \\
\text { BBzP, MEP, MEHP, MBP, } \\
\text { MiBP, MiNP, MBzP }\end{array}$ & $\begin{array}{l}\text { Guraya 1977, Hirshfield } \\
\text { 1991, Gregoraszczuk } \\
\text { et al. 2005, Bellingham } \\
\text { et al. 2013, Wang et al. } \\
\text { 2013, 2014, Johansson } \\
\text { et al. 2016, Lea et al. } \\
\text { 2016, Zhou et al. 2017a, } \\
\text { Hernández-Ochoa et al. } \\
\text { 2018, Samardzija } \\
\text { Nenadov et al. } 2018\end{array}$ \\
\hline Bisphenols & $\begin{array}{l}\text { Used in the manufacturing } \\
\text { of polycarbonate plastics } \\
\text { and epoxy resins. They are } \\
\text { found in food storage } \\
\text { containers, thermal receipt } \\
\text { papers, medical } \\
\text { equipment, and industrial } \\
\text { piping. }\end{array}$ & $\begin{array}{l}\text { Consumption of } \\
\text { contaminated food } \\
\text { products and } \\
\text { environmental exposure } \\
\text { from bisphenols leaching } \\
\text { out of products }\end{array}$ & BPA & $\begin{array}{l}\text { Gregoraszczuk et al. } \\
\text { 2005, Wang et al. 2013, } \\
\text { Ben-Jonathan \& Hugo } \\
\text { 2016, Lea et al. 2016, } \\
\text { Zhou et al. 2017a, } \\
\text { Samardzija Nenadov } \\
\text { et al. } 2018\end{array}$ \\
\hline \multicolumn{5}{|l|}{ Flame retardants } \\
\hline PCBs & $\begin{array}{l}\text { Used as coolants and } \\
\text { solvents in electrical } \\
\text { equipment, rubber } \\
\text { products, and paints }\end{array}$ & $\begin{array}{l}\text { Consumption of } \\
\text { contaminated fish and } \\
\text { environmental exposure } \\
\text { from PCBs leaching out of } \\
\text { products }\end{array}$ & $\begin{array}{l}\text { PCB: } 28,52,101,118,126, \\
\text { 138, 153, } 180\end{array}$ & $\begin{array}{l}\text { Guraya 1977, Borgert } \\
\text { et al. 2004, Prevention } \\
\text { 2009, Karpeta \& } \\
\text { Gregoraszczuk 2010, } \\
\text { Patisaul \& Jefferson } \\
\text { 2010, Kaprara \& } \\
\text { Huhtaniemi 2018, } \\
\text { Pollock et al. 2018 }\end{array}$ \\
\hline $\begin{array}{l}\text { Brominated flame } \\
\text { retardants }\end{array}$ & $\begin{array}{l}\text { Used as coolants in } \\
\text { electronics, furniture, and } \\
\text { textiles }\end{array}$ & Inhalation of dust & $\begin{array}{l}\text { PBDE: } 28,47,99,100,153 \\
\text { 154, 183, 209; DE: 71, 79, } \\
\text { decaBDE209; HBCD, TBBPA }\end{array}$ & $\begin{array}{l}\text { Guraya 1977, Rice et al. } \\
\text { 2006, Prevention 2009, } \\
\text { Kassotis et al. 2016, } \\
\text { World Health } \\
\text { Organization 2017, } \\
\text { Kaprara \& Huhtaniemi } \\
\text { 2018, Pollock et al. } \\
2018\end{array}$ \\
\hline \multicolumn{5}{|l|}{ Phytoestrogens } \\
\hline Isoflavones & $\begin{array}{l}\text { Plant-derived estrogens } \\
\text { found in legumes, } \\
\text { especially soybeans and } \\
\text { clover }\end{array}$ & $\begin{array}{l}\text { Consumption of soy-based } \\
\text { food products like tofu and } \\
\text { soymilk as well as over the } \\
\text { counter dietary } \\
\text { supplements }\end{array}$ & $\begin{array}{l}\text { Genistein, daidzein, } \\
\text { biochanin A, glycetin }\end{array}$ & $\begin{array}{l}\text { Campagna et al. 2001, } \\
\text { Kraugerud et al. 2012, } \\
\text { Schmitz et al. 2018, } \\
\text { Sciences } 2020\end{array}$ \\
\hline Flavones & $\begin{array}{l}\text { Plant-derived estrogens } \\
\text { found in red and yellow } \\
\text { fruits and vegetables }\end{array}$ & $\begin{array}{l}\text { Consumption of red and } \\
\text { yellow fruits and vegeta- } \\
\text { bles as well as over the } \\
\text { counter dietary } \\
\text { supplements }\end{array}$ & Apigenin, quercetin & $\begin{array}{l}\text { Campagna et al. 2001, } \\
\text { Schmitz et al. } 2018\end{array}$ \\
\hline
\end{tabular}


Table 1 Continued.

\begin{tabular}{|c|c|c|c|c|}
\hline & Description & Exposure & Chemicals & References \\
\hline \multicolumn{5}{|l|}{ Pharmaceuticals } \\
\hline Non-steroidal drugs & $\begin{array}{l}\text { Drugs synthesized for } \\
\text { treating, curing, or } \\
\text { preventing diseases }\end{array}$ & $\begin{array}{l}\text { Over the counter or } \\
\text { prescription use }\end{array}$ & $\begin{array}{l}\text { Paracetamol, diclofenac, } \\
\text { naproxen, triclosan, } \\
\text { carbamazepine, irbesartan }\end{array}$ & $\begin{array}{l}\text { Gregoraszczuk et al. } \\
\text { 2005, Fowler et al. 2008, } \\
\text { Lea et al. 2016, } \\
\text { Samardzija Nenadov } \\
\text { et al. } 2018\end{array}$ \\
\hline \multicolumn{5}{|l|}{ Cosmetics } \\
\hline Parabens & $\begin{array}{l}\text { Used as preservatives and } \\
\text { anti-microbials in food } \\
\text { products and cosmetics }\end{array}$ & $\begin{array}{l}\text { Consumption of } \\
\text { contaminated food } \\
\text { products and use of } \\
\text { cosmetics }\end{array}$ & Butyl paraben, propyl paraben & $\begin{array}{l}\text { Gregoraszczuk et al. } \\
\text { 2005, Bellingham et al. } \\
\text { 2013, Samardzija } \\
\text { Nenadov et al. } 2018\end{array}$ \\
\hline UV-filters & $\begin{array}{l}\text { Used in sunscreens, } \\
\text { hairsprays, and other } \\
\text { cosmetics to prevent } \\
\text { damage from sun } \\
\text { exposure }\end{array}$ & $\begin{array}{l}\text { Use of cosmetics containing } \\
\text { UV-filters }\end{array}$ & 4-MBC, OMC & $\begin{array}{l}\text { Gregoraszczuk et al. } \\
\text { 2005, Bellingham et al. } \\
\text { 2013, Lea et al. } 2016\end{array}$ \\
\hline \multicolumn{5}{|l|}{ Industrial by-products } \\
\hline $\begin{array}{l}\text { Polycyclic aromatic } \\
\text { hydrocarbons }\end{array}$ & $\begin{array}{l}\text { By-products of the } \\
\text { incomplete combustion of } \\
\text { organic materials } \\
\text { including coal, gas, oil, } \\
\text { and wood }\end{array}$ & $\begin{array}{l}\text { Inhalation of contaminated } \\
\text { air from cigarettes and } \\
\text { vehicle exhausts as well as } \\
\text { consumption of grilled or } \\
\text { charred foods }\end{array}$ & $\begin{array}{l}\text { Naphthalene, acenaphthylene, } \\
\text { acenaphthene, fluorene, } \\
\text { phenanthrene, anthracene, } \\
\text { fluoranthene, pyrene, } \\
\text { benzo[a]anthracene, } \\
\text { chrysene, benzo[b] } \\
\text { fluoranthene, benzo[k] } \\
\text { fluoranthene, benzo[a] } \\
\text { pyrene, indeno[1,2,3-cd] } \\
\text { pyrene, dibenzo[a,h] } \\
\text { anthracene, benzo[ghi] } \\
\text { perylene }\end{array}$ & $\begin{array}{l}\text { Guraya 1977, } \\
\text { Gregoraszczuk et al. } \\
2008 a\end{array}$ \\
\hline $\begin{array}{l}\text { Hydraulic fracturing } \\
\text { chemicals }\end{array}$ & $\begin{array}{l}\text { The wastewater from } \\
\text { hydraulic fracturing } \\
\text { processes is highly } \\
\text { contaminated with both } \\
\text { organic and inorganic } \\
\text { chemicals }\end{array}$ & $\begin{array}{l}\text { Environmental exposure to } \\
\text { contaminated water }\end{array}$ & $\begin{array}{l}\text { 1,2,4-Trimethylbenze, } \\
\text { 2-(2-methoxyethoxy) } \\
\text { ethanol, 2-ethylhexanol, } \\
\text { 2-methyl-4-isothiazolin- } \\
\text { 3-one, acrylamide, benzene, } \\
\text { bronopol, cumene, } \\
\text { diethanolamine, ethoxylated } \\
\text { nonylphenol, ethoxylated } \\
\text { octyphenol, ethylbenzene, } \\
\text { ethylene glycol, ethylene } \\
\text { glycol monobutyl ether, } \\
\text { naphthalene, N,n-dimethyl- } \\
\text { formamide, phenol, } \\
\text { propylene glycol, sodium } \\
\text { tetraborate decahydrate, } \\
\text { styrene, toluene, triethylene } \\
\text { glycol, xylenes }\end{array}$ & $\begin{array}{l}\text { Gregoraszczuk et al. } \\
2008 b\end{array}$ \\
\hline
\end{tabular}

4-MBC, 4-methylbenzylidenecamphor; BBzP, butyl benzyl phthalate; DBP, dibutyl phthalate; DDD, dichlorodiphenyldichloroethane; DDE, dichlorodiphenyldichloroethylene; DDT, dichlorodiphenyltrichloroethane; DEET, N, N-diethyl-meta-toluamide; DEHP, di(2-ethylhexyl) phthalate; DEP, diethyl phthalate; DiBP, diisobutyl phthalate; DiNP, diisononyl phthalate; HBCD, hexabromocyclododecane; MBP, monobutyl phthalate; MBzP, monobenzyl phthalate; MEHP, mono(2-ethylhexyl) phthalate; MEP, monoethyl phthalate; MiBP, monoisobutyl phthalate; MiNP, monoisononyl phthalate; MXC, methoxychlor; OMC, octyl methoxycinnamatePAHs, polycyclic aromatic hydrocarbons; PCBs, polychlorinated biphenyls; TBBPA, tetrabromobisphenol A; $\alpha-\mathrm{HCH}$, $\alpha$-hexachlorocyclohexane; $\beta$ - $\mathrm{HCH}$, $\beta$-hexachlorocyclohexane.

mixtures during embryonic ovarian development can and have been shown to affect ovarian morphology in a way that has negative consequences for ovarian function. Abnormal ovarian morphology, including weight discrepancies, irregular proportions of follicle populations, atretic follicles, cysts, and fibrosis are all indicative of functional pathology (Hernández-Ochoa et al. 2018).

Although no studies have examined the effects of chemical mixtures on germ cell nest formation and breakdown, studies do show that mixtures can alter gene expression or protein levels in the developing ovary. For example, a mixture of nonsteroidal pharmaceuticals (paracetamol, carbamazepine, diclofenac, irbesartan, and naproxen) increased expression of forkhead box L3 (Fox/3), a transcription factor maintained only in female germ cells, during fetal sex determination in juvenile trout (Schmitz et al. 2018). A mixture of both antiandrogenic and estrogenic chemicals (DBP, DEHP, $\mathrm{BPA}$, vinclozolin, prochloraz, procymidone, linuron, 
epoxiconazole, $p, p^{\prime}-\mathrm{DDE}, 4-\mathrm{MBC}, \mathrm{OMC}$, paracetamol, and butyl paraben) dysregulated 106 proteins compared to control in the ovaries of Wistar rats exposed during ovarian development. The proteins identified were involved in post-transcriptional RNA processing, cytoskeletal organization, intracellular trafficking, and detoxification (Johansson et al. 2020). A mixture of antiandrogenic chemicals (DBP, DEHP, vinclozolin, prochloraz, procymidone, linuron, epoxiconazole and $p, p^{\prime}$-DDE) dysregulated 19 proteins compared to control in ovaries from developmentally exposed Wistar rats. The dysregulated proteins were involved in nuclear transport, cytoskeletal organization, and metabolism (Johansson et al. 2020). A mixture of estrogenic chemicals (4-MBC, OMC, BPA, and butyl paraben) dysregulated 12 proteins compared to control in the ovaries of developmentally exposed Wistar rats. The dysregulated proteins were involved in translation and intracellular signal transduction that are active during ovarian development (Johansson et al. 2020). In addition, in utero exposure to a mixture of endocrine disrupting chemicals (DEHP, PCB congeners: 28, 52, 101, 118, 138, 153, and 180, PBDE congeners: 28, 47, 99, 100, 153, 154, 183, and PAHs: naphthalene, acenaphthylene, acenaphthene, fluorene, phenanthrene, anthracene, fluoranthene, pyrene, benzo[a]anthracene, chrysene, benzo[b] fluoranthene, benzo[k]fluoranthene, benzo[a]pyrene, indeno[1,2,3-cd]pyrene, dibenzo[a,h]anthracene, and benzo[ghi]perylene) reduced total oocyte densities and expression of growth differentiation factor (GDF9), an ovarian growth factor involved in oocyte development, growth and function in sheep. (Fowler et al. 2008). Further, temporal exposure to the mixture resulted in differential expression of several transcripts in the
ERK/MAPK and PI3K/AKT signaling cascades, which are heavily involved in somatic and germ cell dialogue during early proliferation and migration events (Lea et al. 2016).

\section{Effects of chemical mixtures on folliculogenesis}

Folliculogenesis is the process through which immature follicles mature to hormone-secreting follicles capable of ovulation (Hirshfield 1991). The process begins with primordial follicles, which contain an oocyte surrounded by one layer of squamous granulosa cells. The single granulosa cell layer transforms into a cuboidal granulosa layer and the follicles are now referred to as primary follicles (Hirshfield 1991). Primary follicles mature to secondary follicles in which the oocyte is surrounded by many layers of granulosa cells. Surrounding these many layers of granulosa cells is a thin layer of squamous theca cells. The follicle, now complete with all its cellular components, continues to grow until it becomes a mature antral follicle (Hirshfield 1991). The antral follicle is complete with an oocyte surrounded by many layers of granulosa cells and outer thecal cell layers. The mature antral follicle also contains an antrum, a fluid filled space that contains steroid hormones, proteins, polysaccharides, and other maintenance and signaling molecules. The antral follicle is the only follicle capable of ovulation and it is equipped with the cellular machinery to provide the ovary and the rest of the body with adequate estradiol and testosterone (Hirshfield 1991). For this reason, it is often referred to as the functional unit of the ovary and it is the subject of many ovarian toxicology studies. Mixtures of chemicals that are toxic to ovarian follicles can impact the number

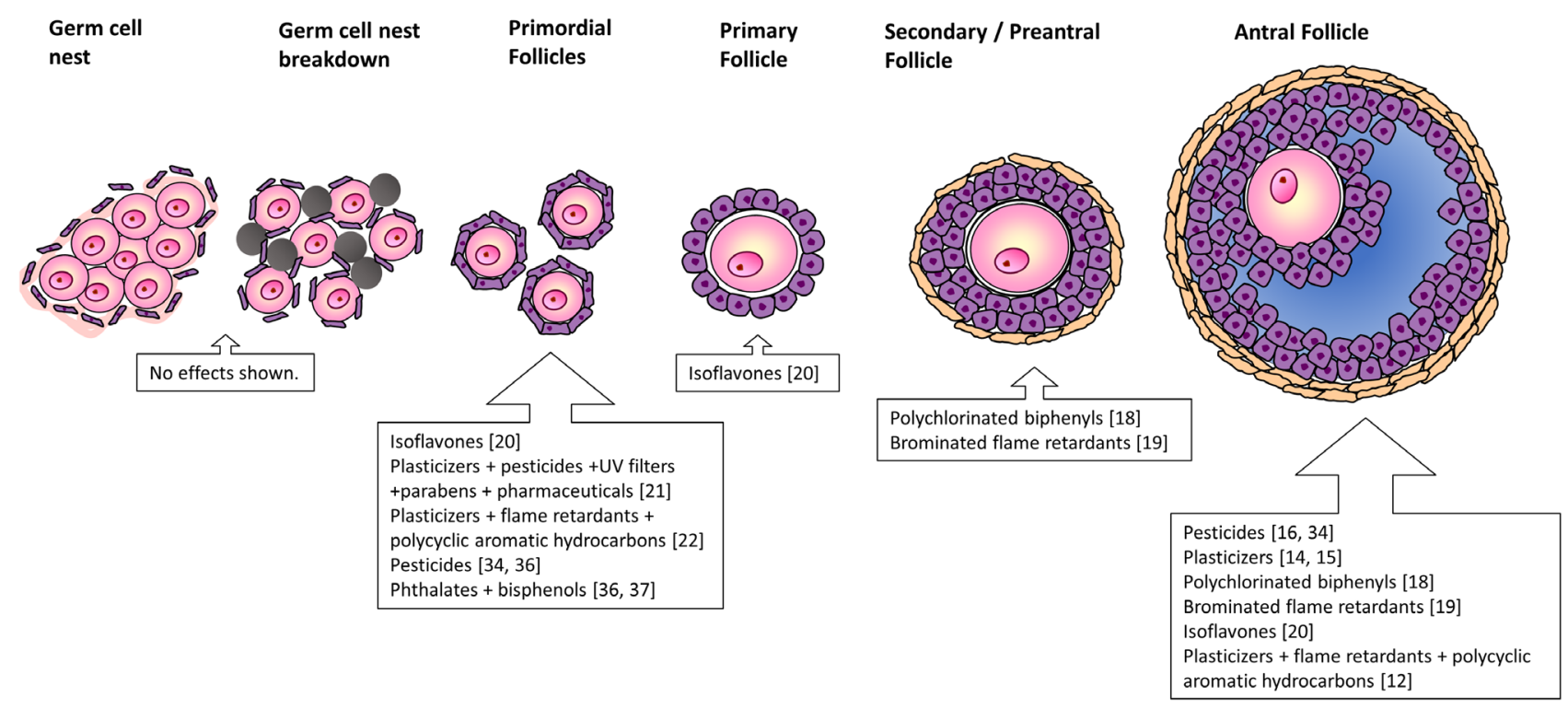

Figure 1 Schematic of development of the primordial follicle pool and folliculogenesis showing chemical mixtures that affect each follicle stage. Oocytes are pink, granulosa cells are purple, and theca cells are yellow. 
of viable oocytes available for fertilization and interfere with the production of sex steroid hormones. Importantly, women are born with a finite number of primordial follicles (Guraya 1977). Ovarian toxicants that interfere with any stage of folliculogenesis might accelerate the rate at which the primordial follicle pool is depleted, leading to infertility due to premature ovarian failure and other ovarian pathologies (Hernández-Ochoa et al. 2018). Refer to Fig. 1 for a schematic of folliculogenesis showing chemical mixtures that affect each follicle stage.

Several studies have shown that mixtures can adversely affect follicle growth and death in vitro. A mixture of phthalate metabolites (MEP, MEHP, MBP, MiBP, MiNP, MBzP) inhibited growth of mouse antral follicles compared to control (Meling et al. 2020). This inhibition of follicle growth is likely due to mixtureinduced effects on expression of cell cycle regulators and apoptotic factors (Meling et al. 2020). It also could be due to the phthalate metabolite mixture affecting expression of several receptors and receptor associated genes compared to control (Meling et al. 2020). Namely, the mixture dysregulated expression of peroxisome proliferator-activated receptors, the aryl hydrocarbon receptor $(A h r)$, and hormone receptors compared to control (Meling et al. 2020). A similar study showed that a phthalate mixture (DEHP, DEP, DBP, DiBP, BBzP, DiNP) increased fragmented oocytes and reduced expression of antioxidant enzymes compared to control (Zhou \& Flaws 2017). A mixture of 10 different organochlorine pesticides (Aroclor, chlordane, $p, p^{\prime}$-DDT, $p, p^{\prime}$-DDE, taxophene, $\alpha \mathrm{HCH}$, aldrin, dieldrin, 1,2,4,5-tetrachlorobenzene, $p, p^{\prime}$-DDD, $\beta \mathrm{HCH}$, hexachlorobenzene, mirex, lindane, and pentachlorobenzene) reduced cumulus expansion and reduced cumulus cell viability in porcine cumulus oocyte complexes compared to control (Campagna et al. 2001). Collectively, these in vitro studies indicate that mixtures can adversely affect follicle health.

Studies have also shown that mixtures can affect folliculogenesis in vivo. A mixture of PCBs, PBDEs, and $p, p^{\prime}$-DDT suppressed ovarian follicle development by reducing follicular proliferation and increasing apoptosis in zebra fish (Kraugerud et al. 2012). In utero and lactational exposure to Aroclor 1016, a commercially prepared PCB mixture, significantly reduced the numbers of preantral and antral follicles as well as increased atresia of antral follicles in the ovaries of exposed rats compared to control (Baldridge 2003). A mixture of PBDEs (DE-71, DE-79, decaBDE-209, and HBCD) increased preantral and antral follicle numbers and enlarged antral follicles compared to control in Sprague Dawley rats (Lefèvre et al. 2016). A mixture of soy isoflavones (genistein, daidzein, and glycetin) decreased the numbers of primordial and primary follicles, increased the numbers of atretic follicles, and increased the number of large antral follicles compared to control in Wistar rats. Further, the follicles of the exposed rats had higher occurrences of multiple and binuclear oocytes compared to control (Wang et al. 2013). In addition, the follicular fluid of the exposed rats contained less estradiol and progesterone and more cholesterol and cortisol compared to control (Wang et al. 2013). Perinatal exposure to a mixture of phthalates (DBP and DEHP), pesticides (vinclozolin, prochloraz, procymidone, linuron, epoxiconazole, $\left.p, p^{\prime}-\mathrm{DDE}\right)$, UV-filters (4-MBC and OMC), BPA, butylparaben, and paracetamol significantly reduced primordial follicle numbers in rats. The mixture also caused irregular estrous cycles and reduced ovarian weights compared to control when animals reached 1 year of age (Johansson et al. 2016). Prenatal exposure to a mixture of 23 hydraulic fracturing chemicals caused dose dependent disruptions in folliculogenesis, with an overall increase in atretic follicles compared to control in the F1 offspring of C57Bl/6 mice (Kassotis et al. 2016). Another mixture (DEHP, PCB congeners: 28, 52, 101, 118, 138, 153, and 180, PBDE congeners: 28, 47, 99, 100, 153, 154, 183, and PAHs: naphthalene, acenaphthylene, acenaphthene, fluorene, phenanthrene, anthracene, fluoranthene, pyrene, benzo[a]anthracene, chrysene, benzo[b] fluoranthene, benzo[k]fluoranthene, benzo[a]pyrene, indeno[1,2,3-cd]pyrene, dibenzo[a,h]anthracene, and benzo[ghi]perylene) increased cell death in ovarian follicles and increased the numbers of mature follicles in the ovaries of in utero exposed offspring compared to control ewes (Fowler et al. 2008). The mixture also caused differential expression of proteins involved in gene expression/transcription, protein synthesis, phosphorylation, and receptor activity in the ovarian tissues of exposed offspring compared to control in ewes (Fowler et al. 2008). Further, ewes exposed to the same mixture after conception had significantly decreased primordial follicle numbers compared to ewes treated during preconception and compared to control (Bellingham et al. 2013). Interestingly, these changes were observed only in ewes temporarily exposed to the mixture and not observed in the ewes exposed to the mixture continuously throughout gestation (Lea et al. 2016). Collectively, these results show that chemical mixtures adversely affect the process of folliculogenesis as well as follicle health in vivo.

\section{Effects of chemical mixtures on steroidogenesis}

The antral follicle is the primary hormone secreting unit within the ovary. In response to follicle-stimulating hormone (FSH) and luteinizing hormone ( $\mathrm{LH})$ from the anterior pituitary, theca cells and granulosa cells work together to produce the sex steroid hormones estradiol and testosterone (Hirshfield 1991). Cholesterol is transported into the theca cell by steroidogenic acute regulatory (STAR) (STAR) protein. It is then converted to pregnenolone by cholesterol side-chain cleavage enzyme (CYP11A1). Pregnenolone can be converted 
to dehydroepiandrosterone by cytochrome P450 17A1 (CYP17A1) or it can be converted to progesterone by 3B-hydroxysteroid dehydrogenase (HSD3B1). Dehydroepiandrosterone and progesterone can both be converted to androstenedione by the same two enzymes. Androstenedione can remain in the theca cell where it is converted to testosterone by 17B-hydroxysteroid dehydrogenase (HSD17B) or it can diffuse into the granulosa cell where it is converted to estrone by aromatase (CYP19A1). Estrone is finally converted to estradiol by HSD17B. Testosterone can also diffuse into the granulosa cell where it is terminally converted to estradiol by CYP19A1. Many ovarian toxicants are endocrine disrupting chemicals, which interfere with the ability of the ovary to synthesize and metabolize estradiol and testosterone. Hormonal imbalances resulting from an excess or deficiency in sex steroid hormones is associated with adverse fertility and health outcomes in women (Vannuccini et al. 2016). Refer to Fig. 2 for a schematic of steroidogenesis showing mixtures that affect expression of steroidogenic regulators.

Several in vitro studies indicate that chemical mixtures can affect ovarian steroidogenesis. A mixture of $p, p^{\prime}$-DDE and MXC inhibited testosterone production compared to control in cultured female bass gonads (Borgert et al. 2004). A mixture of phthalate metabolites (MEP, MEHP, MBP, MiBP, MiNP, MBzP) increased expression of Star, but decreased expression of all downstream steroidogenic enzymes compared to control in cultured mouse follicles (Meling et al. 2020). Further, the mixture increased the concentration of pregnenolone, progesterone, androstenedione, testosterone, and estradiol in the media at $24 \mathrm{~h}$ and it increased the concentrations of DHEA, androstenedione, and testosterone and decreased the concentration of estradiol compared to control at $96 \mathrm{~h}$ (Meling et al. 2020). The mixture-induced decrease in estradiol corresponds to upregulation of Cyp1a1, an enzyme that metabolizes estradiol (Meling et al. 2020). A mixture of estrogenic extracts isolated from untreated wastewater increased expression of the steroidogenic factors Star and Hsd3B1 in cultured mouse granulosa cells (Samardzija Nenadov et al. 2018). This effect was likely mediated through activation of estrogen receptors (Samardzija Nenadov et al. 2018). In other studies, a PBDE mixture (PBDE $47,99,100$, and 209) was applied to co-cultured theca and granulosa cells in low $(0.5 ; 0.25 ; 0.1 ; 0.05 \mathrm{ng} /$ $\mathrm{mL})$, medium $(25 ; 10 ; 4.0 ; 0.25 \mathrm{ng} / \mathrm{mL})$, and high $(50$; $17.5 ; 12.5 ; 0.5 \mathrm{ng} / \mathrm{mL}$ ) doses in short term and longterm culture periods. In the short-term experiments, low doses of the mixture increased estrogen, testosterone and progesterone secretion compared to control (Karpeta \& Gregoraszczuk 2010). In the long-term experiments, medium doses of the mixtures stimulated estradiol and testosterone secretion, and the low, medium, and high dose mixtures stimulated progesterone secretion compared to control (Karpeta \& Gregoraszczuk 2010). These effects were irreversible after removal of mixture regents (Karpeta \& Gregoraszczuk 2010). Further, studies show that the commercial PCB mixture Delor 103 increased testosterone secretion after a single exposure and stimulated estradiol secretion after permanent treatment compared to control in cultured porcine theca interna and granulosa cells. The PCB mixture Delor 106 had antiestrogenic effects on the cultured cells after a single exposure and significant estrogenic effects on the permanently treated cells compared to control (Gregoraszczuk et al. 2005). In addition, exposure to a mixture of persistent organic pollutants (POPs) (p, $p^{\prime}$-DDE, PCB-138, PCB-153, p, $p^{\prime}$-DDD, and $\mathrm{CHB}$ 50) decreased concentrations of estradiol and progesterone and increased the concentrations of testosterone in the media of cultured ovarian cells compared to control (Gregoraszczuk et al. 2008b).

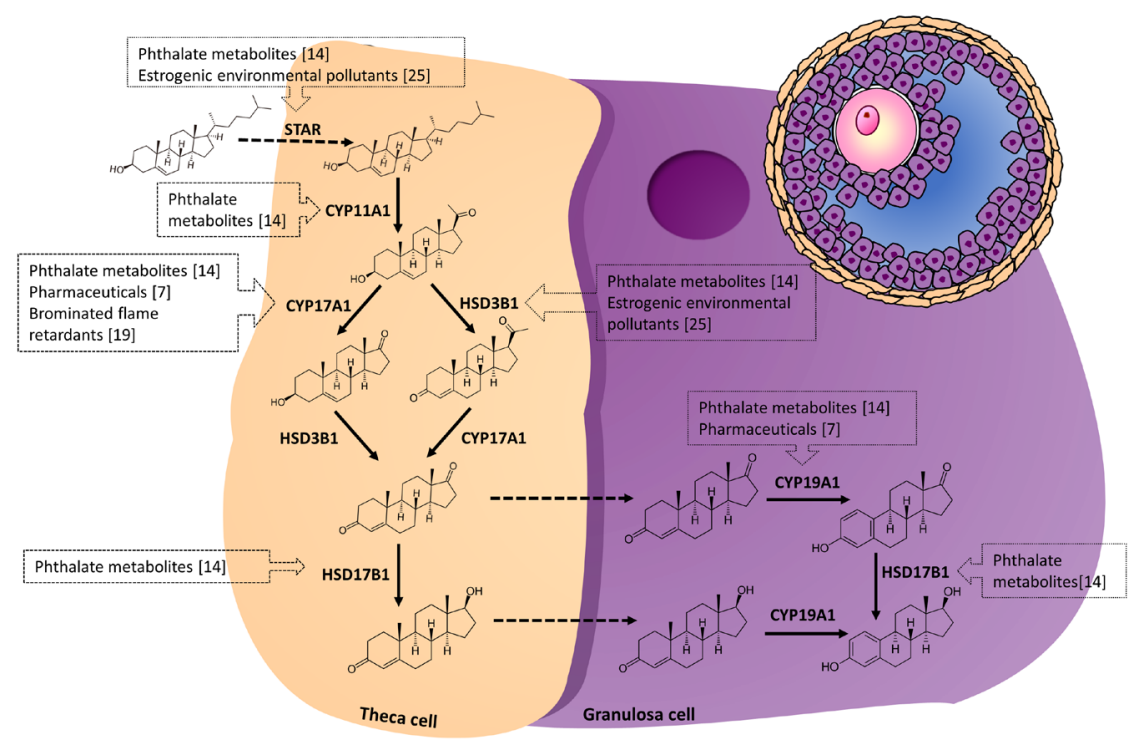

Figure 2 Schematic of steroidogenesis in ovarian follicular cells showing which mixtures affect expression of steroidogenic regulators. Granulosa cells are depicted in purple and theca cells are depicted in yellow. 
Exposure to the same mixture diluted by factors of 2, 4, $20,40,200$, and 1,000 increased the concentrations of estradiol, progesterone, and testosterone in the cultured ovarian cells compared to control. A different mixture of POPs (BDE-47, BDE-99, HBCD, BDE-100, and p, $p^{\prime}-$ DDE) increased the concentrations of estrogen and testosterone in the media of cultured ovarian follicles compared to control (Gregoraszczuk et al. 2008b). In contrast, the mixture decreased the concentration of progesterone in the media of cultured ovarian cells compared to control. Exposure to a third mixture of POPs ( $p, p^{\prime}-\mathrm{DDE}, \mathrm{HBCD}, \mathrm{BDE}-47, \mathrm{PCB}-153$, and BDE99) decreased the concentrations of estradiol and progesterone in the cultured ovarian cells compared to control and increased the concentration of testosterone in the media of cultured ovarian cells compared to control (Gregoraszczuk et al. 2008b). Exposure to the same mixture diluted by factors of 2, 4, 20, 40, 200, and 1000 yielded significantly more profound effects than the undiluted mixture (Gregoraszczuk et al. 2008b).

A PCB $+p, p^{\prime}$-DDT mixture (PCB-153, 126, 118, 138, $180, p, p^{\prime}$-DDT) decreased estradiol and testosterone in the media of cultured porcine ovarian cells compared to control. When $p, p^{\prime}$-DDT was replaced with $p, p^{\prime}$-DDE, the mixture increased estradiol and decreased testosterone levels compared to control in cultured porcine ovarian cells. When both $p, p^{\prime}$-DDT and $p, p^{\prime}$-DDE were used in the mixture, the mixture increased the concentration of estradiol and decreased the concentration of testosterone compared to control in the media of cultured porcine ovarian cells (Gregoraszczuk et al. 2008c). A mixture of BDEs (BDE-47, BDE-99. BDE-100, BDE-209) increased estradiol and testosterone in the media of cultured porcine ovarian cells compared to control (Gregoraszczuk et al. 2008a). The addition of $p, p^{\prime}$-DDT to the mixture increased the concentrations of testosterone, but did not affect estradiol concentrations compared to control in the media of cultured porcine ovarian cells (Gregoraszczuk et al. 2008a). The addition of $p, p^{\prime}$-DDE to the mixture increased the concentrations of estradiol and testosterone compared to control in cultured porcine ovarian cells. The addition of both $p, p^{\prime}$-DDT and $p, p^{\prime}$-DDE to the BDE mixture increased the concentrations of both estradiol and testosterone compared to control in cultured porcine ovarian cells (Gregoraszczuk et al. 2008a). Collectively, these studies show that mixtures can affect the production of sex steroid hormones in various ovarian culture systems.

Studies also show that mixtures affect steroidogenesis in vivo. Specifically, a mixture of nonsteroidal pharmaceuticals (paracetamol, carbamazepine, diclofenac, irbesartan, and naproxen) significantly increased plasma 11-ketotestosterone and plasma estradiol as well as increased ovarian expression of estrogen receptor beta (Esr1), and steroidogenic factors Cyp17a1, Cyp19a1, and Hsd11B in female juvenile trout (Schmitz et al. 2018). A mixture of PBDEs (DE-71, DE-79, decaBDE-209, and hexabromocyclododecane) decreased ovarian expression of Cyp17a1 as well as circulating levels of 17-hydroxypregnenoline and increased testosterone in rats (Lefèvre et al. 2016). Interestingly, exposure to a mixture of triclosan, tetrabromobisphenol A (TBBPA), butyl paraben, propyl paraben, and DEHP led to elevated concentrations of BPA in the ovaries and increased urinary estradiol concentrations compared to control in CF1 mice, suggesting that toxicant mixtures compete for enzymes in BPA and estrogen metabolic pathways (Pollock et al. 2018).

\section{Effects of chemical mixtures on corpora lutea}

Formation of the $\mathrm{CL}$ results from remodeling, growth, and differentiation of theca and granulosa cells in response to a $\mathrm{LH}$ surge from the anterior pituitary. Once formed, the primary function of a CL is to synthesize and secrete progesterone, which is necessary for initiation and maintenance of a successful pregnancy. The CL has a short lifespan. If pregnancy does not occur, the $\mathrm{CL}$ stops producing progesterone and undergoes regression.

A few studies show that mixtures can affect the function of the $\mathrm{CL}$ in vitro and in vivo. For example, exposure to a mixture of isoflavones (biochanin A, genistein and daidzein) reduced Cyp19a1 mRNA expression and activity compared to control in cultured granulosa-luteal cells (Rice et al. 2006). A mixture of the flavones apigenin and quercetin reduced aromatase activity compared to control in cultured granulosa-luteal cells (Rice et al. 2006). A mixture of soy isoflavones (genistein, daidzein, and glycetin) increased the numbers of CLs and the numbers of apoptotic cells in the CLs compared to control in Wistar rats (Wang et al. 2013, 2014). Collectively, these studies indicate that mixtures of phytoestrogens adversely affect CLs in vitro and in vivo.

\section{Transgenerational effects of chemical mixtures on the ovary}

Exposures to chemical mixtures during fetal development can cause permanent changes to the ovarian epigenome, resulting in adverse reproductive outcomes later in adult life such as infertility, primary ovarian insufficiency, and polycystic ovarian syndrome (PCOS) (Nilsson et al. 2012). Specifically, prenatal exposure to an environmentally relevant phthalate mixture (DEHP, DEP, DBP, DiNP, DiBP, $\mathrm{BBz} P$ ) increased ovarian cysts compared to control in CD-1 mice (Zhou et al. 2017b). Prenatal exposure to either a pesticide mixture (permethrin and DEET) or a plastics mixture (BPA, DEHP, DBP) from gestational day 8 to 14 caused reproductive abnormalities in the $\mathrm{F} 3$ generation of Sprague Dawley rats. Specifically, the plastics mixture caused early onset puberty compared to control and both the pesticide and plastics mixtures caused a significant decrease in the primordial follicle pool compared to 
control (Manikkam et al. 2012). In a similar study with the same mixtures and same dosing paradigm, both the pesticide mixture and the plastics mixture reduced primordial follicle numbers compared to control in the F1 and F3 generations. The plastics mixture also increased the numbers of small and large cysts in the F1 generation compared to control, and both mixtures increased small and large cysts in the F3 generation compared to control (Nilsson et al. 2012). Finally, the pesticide mixture reduced large antral follicles in the ovaries of the F3 generation compared to control (Nilsson et al. 2012). In another similar study, gestating Sprague Dawley rats were exposed to a mixture of plasticizers (BPA, DEHP, DBP) from gestational day 8 to 14 . The exposed F1 generation had decreased ovary weights compared to control rats. Both the F1 and F3 generations had increased pubertal abnormalities compared to control rats, including delayed puberty in the F1 generation and early onset puberty in the F3 generation compared to control. Exposed rats in both F1 and F3 generations had primordial follicle loss, an increased number of cysts, and decreased follicular reserve compared to control. Further, the F3 ovaries contained 197 differential DNA methylation regions (DMRs), many of which correlated to the morphological and pathological changes observed in the ovaries of the F3 generation (Nilsson et al. 2012). Collectively, these data show that in utero exposure to a plastics mixture during the period of fetal gonadal sex determination promotes epigenetic transgenerational inheritance of adult onset disease resembling primary ovarian insufficiency and polycystic ovarian syndrome (PCOS).

\section{Conclusion}

The diverse cellular composition and unique processes that happen in the ovary make it a susceptible target for chemical mixtures. The data reviewed come from in vitro experiments designed to test the effects of chemical mixtures directly on ovarian tissue and in vivo experiments which represent ovarian toxicity in the whole reproductive axis. In vitro experiments are useful to understand the mechanisms through which chemical mixtures cause ovarian toxicity in animal studies. Together, these data indicate that chemical mixtures can affect ovarian development, folliculogenesis, and steroidogenesis. However, further studies are required to close the remaining gaps in knowledge regarding the effects of chemical mixtures on the ovary. We need to identify the compositions of environmentally relevant mixtures and study how they affect the ovary. Furthermore, mixtures in the US and EU are currently regulated based on the assumption that chemicals in a mixture either have similar or dissimilar actions and as such are assessed based on the toxicological profiles of each individual component in the mixture (World Health Organization 2017). The data described in this review coupled with human epidemiological data support the notion that chemical mixture interactions are, in fact, more complicated. As such, we need to identify the unique mechanisms of action of chemical mixtures regardless of the mechanisms of their individual chemical components. Through future studies, we can develop a more robust understanding of how mixture components interact with each other and behave differently than they might alone. Using this information on toxicity and mechanisms of action of chemical mixtures, we can develop strategies to prevent or treat mixture-induced toxicity of the ovary.

\section{Declaration of interest}

The authors declare that there is no conflict of interest that could be perceived as prejudicing the impartiality of this review.

\section{Funding}

This work was supported by Interdisciplinary training program in environmental health and toxicology (NIH T32 ES 007326) and NIH R01 ES028661.

\section{Author contribution statement}

V M performed the literature review, wrote the paper, and designed the table and figures. J $F$ revised the paper and figures and approved the final version to be published.

\section{References}

Agency EP 2020. Polychlorinated biphenyls (PCBs) [Online]. (available at: https://www.epa.gov/pcbs/learn-about-polychlorinated-biphenyls-pcbs). Accessed on 10/28/2020.

Baldridge MG, Stahl RL, Gerstenberger SL, Tripoli V \& Hutz RJ 2003 Modulation of ovarian follicle maturation in Long-Evans rats exposed to polychlorinated biphenyls (PCBs) in-utero and lactationally. Reproductive Toxicology 17 567-573. (https://doi.org/10.1016/s08906238(03)00095-9)

Bellingham M, Amezaga MR, Mandon-Pepin B, Speers CJ, Kyle CE, Evans NP, Sharpe RM, Cotinot C, Rhind SM \& Fowler PA 2013 Exposure to chemical cocktails before or after conception - the effect of timing on ovarian development. Molecular and Cellular Endocrinology 376 156-172. (https://doi.org/10.1016/j.mce.2013.06.016)

Ben-Jonathan N \& Hugo ER 2016 Bisphenols come in different flavors: is ' $S$ ' better than 'A'? Endocrinology 157 1321-1323. (https://doi.org/10.1210/ en.2016-1120)

Borgert CJ, Gross TS, Guiney PD, Osimitz TG, Price B \& Wells C 2004 Interactive effects of $\mathrm{p}, \mathrm{p}^{\prime}$-dichlorodiphenyldichloroethylene and methoxychlor on hormone synthesis in largemouth bass ovarian cultures. Environmental Toxicology and Chemistry 23 1947-1956. (https://doi. org/10.1897/03-424)

Campagna C, Sirard MA, Ayotte P \& Bailey JL 2001 Impaired maturation, fertilization, and embryonic development of porcine oocytes following exposure to an environmentally relevant organochlorine mixture. Biology of Reproduction 65 554-560. (https://doi.org/10.1095/ biolreprod65.2.554)

Fowler PA, Dorà NJ, Mcferran H, Amezaga MR, Miller DW, Lea RG, Cash P, Mcneilly AS, Evans NP, Cotinot C et al. 2008 In utero exposure to low doses of environmental pollutants disrupts fetal ovarian development in sheep. Molecular Human Reproduction 14 269-280. (https://doi. org/10.1093/molehr/gan020) 
Gregoraszczuk EL, Zemla M, Ptak A \& Grabic R 2005 The action of lowand high-chlorinated biphenyl mixture on prepubertal porcine ovary: steroid secretion and cells apoptosis. Endocrine Regulations 39 33-41.

Gregoraszczuk Et, Rak A, Kawalec K \& Ropstad E 2008a Steroid secretion following exposure of ovarian follicular cells to single congeners and defined mixture of polybrominateddibenzoethers (PBDEs), p, $\mathrm{p}^{\prime}$-DDT and its metabolite p,p'-DDE. Toxicology Letters 178 103-109. (https:// doi.org/10.1016/j.toxlet.2008.02.011)

Gregoraszczuk EL, Milczarek K, Wojtowicz AK, Berg V, Skaare JU \& Ropstad E 2008b Steroid secretion following exposure of ovarian follicular cells to three different natural mixtures of persistent organic pollutants (POPs). Reproductive Toxicology 25 58-66. (https://doi. org/10.1016/j.reprotox.2007.10.001)

Gregoraszczuk EL, Ptak A, Karniewska M \& Ropstad E 2008c Action of defined mixtures of PCbs, $p, p^{\prime}$-DDT and its metabolite $p, p^{\prime}$-DDE, on co-culture of porcine theca and granulosa cells: steroid secretion, cell proliferation and apoptosis. Reproductive Toxicology 26 170-174. (https://doi.org/10.1016/j.reprotox.2008.07.003)

Guraya SS 1977 Recent advances in the morphology, histochemistry, and biochemistry of the developing mammalian ovary. International Review of Cytology $\mathbf{5 1}$ 49-131. (https://doi.org/10.1016/s00747696(08)60226-0)

Hernández-Ochoa I, Paulose T \& Flaws JA 2018 4.18 - Ovarian toxicology. In Comprehensive Toxicology, 3rd ed. Ed CA Mcqueen. Oxford: Elsevier.

Hirshfield AN 1991 Development of follicles in the mammalian ovary. International Review of Cytology 124 43-101. (https://doi.org/10.1016/ s0074-7696(08)61524-7)

Johansson HK, Jacobsen PR, Hass U, Svingen T, Vinggaard AM, Isling LK, Axelstad M, Christiansen S \& Boberg J 2016 Perinatal exposure to mixtures of endocrine disrupting chemicals reduces female rat follicle reserves and accelerates reproductive aging. Reproductive Toxicology 61 186-194. (https://doi.org/10.1016/j.reprotox.2016.03.045)

Johansson HKL, Svingen T, Boberg J, Fowler PA, Stead D, Vinggaard AM \& Filis P 2020 Calretinin is a novel candidate marker for adverse ovarian effects of early life exposure to mixtures of endocrine disruptors in the rat. Archives of Toxicology 94 1241-1250. (https://doi.org/10.1007/ s00204-020-02697-3)

Kaprara A \& Huhtaniemi IT 2018 The hypothalamus-pituitary-gonad axis: tales of mice and men. Metabolism: Clinical and Experimental 86 3-17. (https://doi.org/10.1016/j.metabol.2017.11.018)

Karpeta A \& Gregoraszczuk E 2010 Mixture of dominant PBDE congeners (BDE-47,-99,-100 and -209) at levels noted in human blood dramatically enhances progesterone secretion by ovarian follicles. Endocrine Regulations 44 49-55. (https://doi.org/10.4149/endo_2010_02_49)

Kassotis CD, Bromfield J, Klemp KC, Meng CX, Wolfe A, Zoeller RT, Balise VD, Isiguzo CJ, Tillitt DE \& Nagel SC 2016 Adverse reproductive and developmental health outcomes following prenatal exposure to a hydraulic fracturing chemical mixture in female $\mathrm{C} 57 \mathrm{Bl} / 6$ mice. Endocrinology 157 3469-3481.

Kraugerud M, Doughty RW, Lyche JL, Berg V, Tremoen NH, Alestrom P, Aleksandersen M \& Ropstad E 2012 Natural mixtures of persistent organic pollutants (POPs) suppress ovarian follicle development, liver vitellogenin immunostaining and hepatocyte proliferation in female zebrafish (Danio rerio). Aquatic Toxicology 116-117 16-23. (https://doi. org/10.1016/j.aquatox.2012.02.031)

Lea RG, Amezaga MR, Loup B, Mandon-Pepin B, Stefansdottir A, Filis P, Kyle C, Zhang Z, Allen C, Purdie L et al. 2016 The fetal ovary exhibits temporal sensitivity to a 'real-life' mixture of environmental chemicals. Scientific Reports 6 22279. (https://doi.org/10.1038/srep22279)

Lefèvre PL, Berger RG, Ernest SR, Gaertner DW, Rawn DF, Wade MG, Robaire B \& Hales BF 2016 Exposure of female rats to an environmentally relevant mixture of brominated flame retardants targets the ovary, affecting folliculogenesis and steroidogenesis. Biology of Reproduction 94 9. (https://doi.org/10.1095/biolreprod.115.134452)

Manikkam M, Guerrero-Bosagna C, Tracey R, Haque MM \& Skinner MK 2012 Transgenerational actions of environmental compounds on reproductive disease and identification of epigenetic biomarkers of ancestral exposures. PLOS ONE 7 e31901. (https://doi.org/10.1371/ journal.pone.0031901)

Meling DD, Warner GR, Szumski JR, Gao L, Gonsioroski AV, Rattan S \& Flaws JA 2020 The effects of a phthalate metabolite mixture on antral follicle growth and sex steroid synthesis in mice. Toxicology and Applied Pharmacology 388 114875. (https://doi.org/10.1016/j. taap.2019.114875)

Nilsson E, Larsen G, Manikkam M, Guerrero-Bosagna C, Savenkova MI \& Skinner MK 2012 Environmentally induced epigenetic transgenerational inheritance of ovarian disease. PLOS ONE 7 e36129. (https://doi. org/10.1371/journal.pone.0036129)

Patisaul HB \& Jefferson W 2010 The pros and cons of phytoestrogens. Frontiers in Neuroendocrinology 31 400-419. (https://doi.org/10.1016/j. yfrne.2010.03.003)

Pollock T, Weaver RE, Ghasemi R \& Decatanzaro D 2018 A mixture of five endocrine-disrupting chemicals modulates concentrations of bisphenol $A$ and estradiol in mice. Chemosphere 193 321-328. (https://doi. org/10.1016/j.chemosphere.2017.11.030)

Prevention CFDCA 2009. Polycyclic aromatic hydrocarbons (PAHs). Available at

Rice S, Mason HD \& Whitehead SA 2006 Phytoestrogens and their low dose combinations inhibit mRNA expression and activity of aromatase in human granulosa-luteal cells. Journal of Steroid Biochemistry and Molecular Biology 101 216-225. (https://doi.org/10.1016/j. jsbmb.2006.06.021)

Samardzija Nenadov D, Pogrmic-Majkic K, Fa S, Stanic B, Tubic A \& Andric N 2018 Environmental mixture with estrogenic activity increases Hsd3b1 expression through estrogen receptors in immature rat granulosa cells. Journal of Applied Toxicology 38 879-887. (https://doi. org/10.1002/jat.3596)

Schmitz M, Beghin M, Mandiki SNM, Nott K, Gillet M, Ronkart S, Robert C, Baekelandt S \& Kestemont P 2018 Environmentally-relevant mixture of pharmaceutical drugs stimulates sex-steroid hormone production and modulates the expression of candidate genes in the ovary of juvenile female rainbow trout. Aquatic Toxicology 205 89-99. (https://doi.org/10.1016/j.aquatox.2018.10.006)

Sciences NIOEH 2020. Pesticides [Online]. (available at: https://www. niehs.nih.gov/health/topics/agents/pesticides/index.cfm). Accessed on 10/28/2020.

Vannuccini S, Clifton VL, Fraser IS, Taylor HS, Critchley H, Giudice LC \& Petraglia F 2016 Infertility and reproductive disorders: impact of hormonal and inflammatory mechanisms on pregnancy outcome. Human Reproduction Update 22 104-115. (https://doi.org/10.1093/ humupd/dmv044)

Wang W, Zhang W, Liu J, Sun Y, Li Y, Li H, Xiao S \& Shen X 2013 Metabolomic changes in follicular fluid induced by soy isoflavones administered to rats from weaning until sexual maturity. Toxicology and Applied Pharmacology 269 280-289. (https://doi.org/10.1016/j. taap.2013.02.005)

Wang W, Sun Y, Liu J, Li Y, Li H, Xiao S, Weng S \& Zhang W 2014 Soy isoflavones administered to rats from weaning until sexual maturity affect ovarian follicle development by inducing apoptosis. Food and Chemical Toxicology 72 51-60. (https://doi.org/10.1016/j.fct.2014.07.010)

Wolrd Health Organization 2017 Chemical Mixtures in Source Water and Drinking Water. Geneva, Switzerland: Wolrd Health Organization.

Zhou C \& Flaws JA 2017 Effects of an environmentally relevant phthalate mixture on cultured mouse antral follicles. Toxicological Sciences $\mathbf{1 5 6}$ 217-229. (https://doi.org/10.1093/toxsci/kfw245)

Zhou C, Chiang C, Brehm E \& Flaws JA 2017 a Chapter 45 - Personal care products and cosmetics. In Reproductive and Developmental Toxicology, 2nd ed. Ed RC Gupta. Academic Press.

Zhou C, Gao L \& Flaws JA 2017b Exposure to an environmentally relevant phthalate mixture causes transgenerational effects on female reproduction in mice. Endocrinology 158 1739-1754. (https://doi. org/10.1210/en.2017-00100)

Received 2 November 2020

First decision 17 December 2020

Revised Manuscript received 11 January 2021

Accepted 29 January 2021 